\title{
Research on Certification Standards of LSQ
}

\author{
Fang Wang, Yangyang Hu \\ Graduate Department, Beijing Wuzi University, Beijing, China \\ Email: littlefang2011@163.com, HYY_2016@126.com
}

Received 4 August 2016; accepted 26 August 2016; published 29 August 2016

Copyright (C) 2016 by authors and Scientific Research Publishing Inc.

This work is licensed under the Creative Commons Attribution International License (CC BY).

http://creativecommons.org/licenses/by/4.0/

(c) (i) Open Access

\begin{abstract}
With the rapid development of the logistics industry, improving the logistics service quality (LSQ) has become the most important means to achieve the competitive advantage for many logistics enterprises. At the same time, as the international prevailing evaluation system, certifications not only are the basic means of quality management, but also the tools to promote the development of trade facilitation. This paper analyzes the connotation of LSQ, and puts forward that for promoting the development of logistics industry and improving customer satisfaction rate, the quality of logistics service should also be certified. Based on the analysis of a large number of literatures and practice, the paper puts forward the construction of LSQ certification standards. Through the analysis, it is concluded that the LSQ plays an important role in regulating the logistics market, improving the competitiveness of enterprises, improving the customer satisfaction rate and avoiding risks.
\end{abstract}

\section{Keywords}

LSQ, Certification, LSQ Certification Standards

\section{Introduction}

The logistics industry is considered to be the artery and basic industry of national economic development in the world. Its development level is a measure of an important symbol of a country's modernization level and the comprehensive national strength. Logistics service quality is the core element to form the competitive advantage of logistics enterprises. It becomes a powerful means for logistics enterprises to guarantee sustainable development by improving logistics quality and customer satisfaction. Perreault and Russ (1974) put forward 7Rs theory based on the point of view of logistics enterprises [1]. Lalonde and Zinzez (1976) defined logistics service as "logistics service is a purposeful activity which aims to meet the customer needs and ensure the customer satisfaction and win praise of enterprises” [2]. The research of Mentzer, Gomes and Krapfe (1989) considered that the LSQ should include two aspects: the physical distribution service quality and the customer marketing service 
quality [3]. American scholars from Tennessee State University concluded that measuring the LSQ should be from the point of nine indicators in 2001, which includes the staff communication quality, order releasing quantity, the quality of information, order processing, accurate rate of goods, soundness of goods, quality of goods, error processing and timeliness. This is a more complete definition of LSQ, and makes measures of the LSQ tend to science.

Since China introduced the concept of LSQ in the late 1970s, the research on the logistics service quality has been carried out. For example, Huang Fuhua (1994) studied the basic ways of Logistics Quality Management [4]; Wang Zhitai (2000) proposed the measure of LSQ indicators, namely, time, cost, quantity and quality [5]; He Yun (2004) proposed that measuring the LSQ can be from two aspects namely external and internal customer [6]. Compared with foreign research emphasizing more on theoretical analysis and empirical research, China's research focuses on theoretical analysis, less application to China's logistics enterprises.

Compared with the developed countries, China's logistics industry is still in the development stage that the overall level of the logistics service quality is not high, the customer satisfaction rate is low, and the logistics enterprise competitiveness is poor. One of the important reasons is that the logistics industry of our country has not a scientific and reasonable logistics service quality measurement methods and standards. In order to promote the healthy, rapid and sustainable development of logistics industry, the logistics industry urgently needs a set of perfect LSQ standard certification to improve LSQ and standardize the development of the logistics industry. Therefore, it has important significance to explore the connotation and construction of LSQ certification standards.

\section{The Connotation of LSQ Certification Standards}

\subsection{LSQ Certification}

GB/T 18354-2006 points out that "the logistics service is defined as a series of results to meet customer demand for logistics activities in the process of being implemented and produce.” General tangible product is the result of the process, but logistics service product itself is the process of logistics services. LSQ is the extent of logistics service process and logistics services result to meet customer needs, achieving customer satisfaction. It's difficult to find a suitable quantized method to evaluate the quality of logistics because the logistics service is not a physical product, and its heterogeneity and complexity characteristics. The customer is not easy to obtain true information about the characteristics of logistics service which leads to wrong decisions and does damage to the interests [7]. Therefore, in order to standardize logistics service provider of logistics services, improve the competitiveness of enterprises and protect the interests of customers, we should take appropriate means confirm whether the LSQ meets the relevant standards and specifications or not-third party organization to prove that the logistics service quality is in line with the relevant standards, namely, LSQ certification.

LSQ certification is beneficial to both sides of supply and demand, and promotes the effective docking of supply and demand sides and benign interaction. For logistics service providers, LSQ certification can help enterprises to standardize logistics service management, improve service quality and enhance the brand image of enterprises in the market. All those aim to enhance the competitiveness of enterprises and expand their profit margins; for the demand side, LSQ certification can provide the correct signal to consumers and help consumers to identify the strengths and weaknesses. This helps the customers make the right decisions and guides rational consumption. At the same time, the signal feedback to the supply side of the logistics consumption market can promote the supply side to strengthen the logistics management, improve the LSQ and provide more high-quality logistics services.

\subsection{LSQ Certification Standards}

LSQ certification standard is the premise and basis of logistics service certification, and it is also the technical basis of certification [8]. LSQ certification standards will affect the certification work.

Different from quality management system certification which has unified certification standards (ISO standards), the basis of service certification is usually related to the service standards, laws and regulations, service commitments, etc. The LSQ certification standards should be comprehensive consideration of the function and characteristics of the logistics service, the relevant legal regulations and technical standards requirements. It should also focus on logistics service society, customers, and other stakeholders, and consider the relevant in- 
ternational conventions and the traffic rules.

From the point of view presented in the form of certification standards, certification standards generally includes qualitative standards and quantitative standards. Qualitative standards are instructive and directional, focusing on the quality of the description, while quantitative criteria are more prescriptive and normative, focusing on quality considerations. Logistics service has different characteristics from general service, and the assessment and improvement of the quality of logistics services also are difficult to find a suitable method to quantify. Therefore, the logistics service quality certification standards should be a combination of qualitative and quantitative standards.

At present, China's logistics quality management related standardization work is slow, and the representative of the national standard of logistics service quality is "logistics enterprise classification and evaluation index" (GB/T19680-2005) [9]. Six first grade indexes of standard is based on operating conditions, assets, equipment, facilities, management and service, personnel quality and the level of information. Three secondary indicators include service management system, quality management, and customers' complaint rate. Two reference indexes includes management system and customer complaint rate. According to those indexes, enterprises are divided to 5 levels, namely, AAAAA-A. And AAAAA level is the highest level. The standard of logistics enterprise rating is based on ISO9001 quality management system certification. However, service quality certification is different from management system certification, so there is a huge difference between "service" and "product". ISO9000 standard is not suitable for application in the logistics industry directly. Therefore, the logistics industry need certification standards urgently which can meet the characteristics of LSQ and strengthen the construction of certification standards system.

\section{Construction of LSQ Certification Standards}

\subsection{The Subject of LSQ Certification}

Logistics service quality certification is the third party which has no interest relationship with the certified object, that is, the subject of logistics service quality certification.

\subsection{The Object of LSQ Certification}

The object of LSQ certification is the logistics enterprises that need to be certificated.

According to the subject of logistics, logistics can be divided into the first party logistics, the second party logistics, the third party logistics, the fourth party logistics, etc. The third party logistics services are provided by the professional logistics enterprises. It is independent on the logistics of the supply side and the demand side, and occupies the larger market share. Therefore, the object of logistics service quality certification is mainly aimed at the third party logistics enterprises.

\subsection{The Scope and Model of LSQ Certification}

Logistics service quality certification scope is the entire process provided by the third party logistics enterprises. It consists of three parts: the front end of LSQ (direct contact with logistics customers at the beginning), process of logistics services (including transport, storage, packing and other logistics activity), the results of logistics services (such as time assurance, product quality and after-sales service).

LSQ certification model is the third party logistics enterprise quality system evaluation + certification after supervision. The basic link of the certification includes the application of certification, quality system assessment, certification evaluation and approval and the supervision after the certification.

\subsection{The Index System of LSQ Certification}

On the basis of a large number of relevant literature and theoretical analysis, this paper proposes LSQ certification standards to meet customer demand and improve customer satisfaction as the premise, including logistics service process and the results of logistics services as shown in Table 1. Specifically, the process of logistics services including:

1) The quality of personnel communication: logistics providers can fully understand customer needs and provide convenient, fast, personalized logistics services through effective communication, including responsible experience ability of the personnel to communicate, customer demand understanding, customer demand response. 
Table 1. LSQ certification standards.

\section{LSQ}

Logistics service quality of the process

communication skills and experience of staff

Communication quality

Understanding of customer needs

Responding to customer demand

Information availability

Information

quality

Information adequacy

The convenience of ordering process

Order processing

Quality

The speed of order response

The efficiency of order operational
Logistics service quality of the results

Delivered to the designated location

Order Logistics distribution goods is consistent

fulfillment with the order

quality Use quality of goods is consistent with customer needs

Time Delivered by commitment time

quality

Logistics Goods soundness

quality

of goods Circulation and processing quality

Error processing quality

2) The quality of information: the availability of information and the adequacy of the information. Those will affect the degree of symmetry between the two sides of supply and demand logistics services, and customers can obtain sufficient information to facilitate the information to make the correct decision.

3) The quality of order processing: including the convenience of logistics suppliers for order process, order response speed, and the operation efficiency of the order.

4) The efficiency of error handling: the handling mode and efficiency of the logistics service provider for order processing errors is an important factor to determine the.

LSQ standards:

1) The quality of order fulfillment: whether the goods are delivered to the designated place; whether the goods are consistent with the order description; whether the goods are in agreement with the customer's requirements.

2) The quality of time: the main point is whether the goods are delivered at the promised time and the whole waiting time of process of logistics service.

3) The quality of goods logistics: mainly refers to the integrity of the goods in the process of logistic and the quality of the circulation of goods.

\section{The Role of LSQ Certification Standards}

1) Regulating the logistics market. China's current logistics market is developing rapidly, and the LSQ is uneven. According to the "China home large logistics industry data report "shows, by 2015 China has been engaged in logistics activities of an enterprise as a legal person units over 30 million and number of employees of logistics are more than 30 million people. It is one of the fastest growing physical industries. China has become worthy of the name of logistics country. However, Chinese logistics enterprises have a considerable portion of the developed from the traditional transport, warehousing enterprises. Most of those enterprises logistics' concepts are backward, and consciousness of service quality is not strong; logistics operation mode and a low level of information technology are backward. Enterprise internal management system is chaos. The LSQ certification standards establish a benchmark and provide guidelines for enterprise logistics so that enterprises can control problems in their own service examination according to the standard, standardize the enterprise's logistics service and promoting the improvement of the overall level of logistics industry.

2) Improving the competitiveness of enterprises. In order to survive, develop and grow in the fierce market competition, logistics enterprises must realize the service nature of logistics industry. LSQ is the core element to form the competitive advantage of the logistics enterprise [10]. The implement of scientific and reasonable LSQ certification standards can improve enterprise LSQ, establish a good corporate brand image and form enterprise competitive advantage.

3) Improving customer satisfaction. The purpose of logistics services is to meet customer needs and ensure 
customer satisfaction. In the development of LSQ certification standards, we should consider customer demand, so that the LSQ certification standards is not only the standard assessment of the service level of logistics enterprises is qualified or not, but also it is a way to improve customer satisfaction. Customer satisfaction rate is the basis for maintaining old customers, attracting new customers and maintaining competitive advantage.

4) Control of enterprise cost. Through the LSQ certification standards, it promotes enterprises to improve the logistics service quality and streamline the related service process. It also improves the internal quality management, reduce unnecessary human and material resources waste, and control enterprise cost.

5) Increasing the profits of enterprises. Experience of DELL and FedEx shows that the LSQ has a significant impact on corporate profits. The improvement of enterprise competitiveness and customer satisfaction rate will help enterprises to expand market share and improve profit margins.

6) Avoiding risks. According to the LSQ certification standards, providing a sound, standardized logistics services helps enterprises to maintain a stable customer base, avoid unnecessary risk of services, and improve risk prevention capabilities. At the same time, through the establishment of international recognition, meeting the needs of the parties to the LSQ certification standards can promote trade facilitation and reduce trade costs and risks [11].

\section{Conclusion}

LSQ certification can not only provide technical support for economic and social development and build confidence in the bridge on both sides of the supply and demand for logistics service, but also is an important supplement of the government regulation to regulate market behavior and facilitate international trade. It is very necessary for the LSQ certification. This paper analyzes the connotation of LSQ certification, and puts forward that the LSQ certification should include two aspects namely the logistics service process and logistics service result. On the analysis of related literature and practical basis, this paper builds LSQ standards and puts forward the process of LSQ including communication quality, information quality, order processing quality and error processing quality. The results of LSQ include quality of orders completed, quality of time, and quality of goods logistics. Scientific and reasonable LSQ certification standards can regulate the logistics market, improve the competitiveness of enterprises, improve customer satisfaction rate, control the cost of enterprise, improve enterprise profits, and avoid risks.

\section{References}

[1] Perrault, W.D. and Russ, F.A. (1974) Physical Distribution Service: A Neglected Aspect of Marketing Management. MSU Business Topics, 22, 37-45.

[2] Lalonde, B.J. and Zinszer, P.H. (1976) Customer Service: Meaning and Measurement. National Council of Physical Distribution Management, Chicago, IL, 156-159.

[3] Mentzer, J.T., Gomes, R. and Krapfel Jr., R.E. (1989) Physical Distribution Service: A Fundamental Marketing Concept. Journal of the Academy of Marketing Science, 17, 53-62. http://dx.doi.org/10.1007/BF02726354

[4] Huang, F.H. (2001) Theoretical Thinking and Analysis on the Way of Logistics Quality Management in Contemporary Enterprise. Science \& Technology Progress and Policy, No. 9, 95-96.

[5] Wang, Z.T. (2000) Modern Logistics. China Material Press, Beijing, 540.

[6] He, Y. and Tian Y. (2004) Analysis on the Conception and Application of Logistics Service Quality. Logistics Technology, No. 2, 11-13.

[7] Chen, H., Tao, L.P. and Wang, Q.Z. (2014) Analysis on the Characteristics of Logistics Service Certification. Shanghai Quality, No. 7, 46-49.

[8] Chen, H., Tao, L.P. and Wang, Q.Z. (2013) Preliminary Study on Several Problems of Quality and Certification on Service Certification. Shanghai Quality, No. 5, 28-31.

[9] Chen, H.-L. and Lu, H. (2013) Study on the Process Quality Evaluation of Cold-Chain Logistics Service. China Business and Market, No. 1, 34-39.

[10] Zhang, X., Chen, H.-L., Li, Y.-L. and Lv, Z.-Q. (2014) The Analysis of Third-party Logistics Enterprises to Implement IS09001 Quality Management System Certification. Logistics Technology, No. 5, 108-110.

[11] Sun, D.W. (2016) Director of the National Commission for Accreditation: Certification and Accreditation to Enhance the Quality of Supply Boost Consumer Confidence. Quality and Certification, No. 4, 20-21. 


\section{Submit or recommend next manuscript to SCIRP and we will provide best service for you:}

Accepting pre-submission inquiries through Email, Facebook, LinkedIn, Twitter, etc.

A wide selection of journals (inclusive of 9 subjects, more than 200 journals)

Providing 24-hour high-quality service

User-friendly online submission system

Fair and swift peer-review system

Efficient typesetting and proofreading procedure

Display of the result of downloads and visits, as well as the number of cited articles

Maximum dissemination of your research work

Submit your manuscript at: http://papersubmission.scirp.org/ 